\title{
Isolated Scaphoid Dislocation: A Case Report and Review of the Literature
}

\author{
Asgeir Amundsen, MD ${ }^{1,2}$ Sarah N. Bishop, MD 3 Steven L. Moran, MD ${ }^{1}$ \\ ${ }^{1}$ Division of Plastic and Reconstructive Surgery, Mayo Clinic, \\ Rochester, Minnesota \\ 2 Department of Orthopedic Surgery, Østfold Hospital Trust, Kalnes, \\ Norway \\ ${ }^{3}$ Department of Plastic Surgery, MD Anderson Cancer Center, \\ Houston, Texas \\ J Wrist Surg 2020;9:431-439.

\begin{abstract}
Address for correspondence Steven Moran, MD, Division of Plastic and Reconstructive Surgery, Mayo Clinic, 200 First Street Southwest, Rochester, MN 55905 (e-mail: moran.steven@mayo.edu).
\end{abstract}

Abstract

\section{Keywords}

- scaphoid dislocation

- scaphoid vascularity

- lunate morphology

- perilunate dislocation

- carpus
Background Isolated scaphoid dislocation is an exceedingly rare event with only 55 cases described. Closed reduction followed by operative intervention with Kirschner's wires (K-wire) fixation and ligamentous reconstruction are the mainstays of treatment. Case Description We describe a patient with a solitary scaphoid dislocation treated with initial closed reduction and urgent open reduction with K-wire stabilization and ligamentous repair. The patient was immobilized for 6 weeks and on 24-month followup, the patient was doing well with no limitations in his daily living, no pain, and acceptable range of motion.

Literature Review A literature review was performed on the 55 cases described in the English language. The majority of the patients were males, aged between 18 and 79 years, and presented with motor vehicle accidents as the most common mechanism. Historically, isolated scaphoid dislocations were treated with closed reduction. However, K-wire fixation and, now, K-wire fixation coupled with ligamentous injury repair remain the current treatments of choice. Avascular necrosis of the scaphoid remains a rare event with only one documented case. Overall, patients do well with only minor pain and limited wrist movements. Notably, only eight cases were associated with type-II lunates. Type-II lunates appear to be protective for carpal injury. Clinical Relevance Although isolated scaphoid dislocations remain a rare event, understanding the anatomy and the current ability to restore carpal anatomy is important. Type-II lunates appear to confer protection from carpal injuries.
Isolated dislocation of the scaphoid is an exceedingly infrequent entity. To date, only 55 cases have been reported in the English language with the first report in $1903 .{ }^{1}$ Isolated scaphoid dislocations are rare due to the complex anatomy and kinematics of the carpal bones. The 20 different ligaments that interconnect the carpal bones provide significant stability and allow flexibility in multiple planes. Mechanisms mainly involve ulnar deviation in a power grip or ulnar deviation with dorsal extension. ${ }^{2,3}$ Motor vehicle accidents are the most

received

December 9, 2019

accepted

March 24, 2020

published online

July 30, 2020 frequent cause starting with the first reported case in $1903{ }^{1}$ Closed reduction has previously been the primary treatment option with a trends toward operative reduction and ligament reconstruction in the last two decades. Fortunately, avascular necrosis of the scaphoid has not proven to be a common complication; however, residual subluxation has been. We present a case of an acute isolated scaphoid dislocation treated with initial closed reduction and subsequent open reduction, internal fixation, and ligament reconstruction.
Copyright $\odot 2020$ by Thieme Medical Publishers, Inc., 333 Seventh Avenue, New York, NY 10001, USA. Tel: +1(212) 760-0888.
DOI https://doi.org/ 10.1055/s-0040-1710395. ISSN 2163-3916. 


\section{Case Report}

A 45-year-old male farmer sustained a closed twisting injury involving the rotating pulley mechanism of a corn auger. He underwent forced supination of his nondominant right wrist as he pulled his hand out of the mechanism. He did not sustain any other injuries. There was no disruption of the skin. He was initially seen at an outside institution, radiographed, splinted, and transferred immediately to our center for definitive management. Radiographs showed an isolated scaphoid dislocation proximal to the distal edge of the radius ( - Fig. 1 ) in addition to a mildly displaced pisiform fracture. He had no neurovascular compromise. The patient was initially reduced in the emergency room under hematoma block by ulnar deviation, longitudinal traction, and manual pressure ( - Fig. 2). Due to the obvious ligamentous injuries, the patient was then taken to the operating room the following morning for exploration and repair of damaged structures. Operative intervention was performed within 24 hours of the original injury.

\section{Surgical Findings}

Under general anesthesia and tourniquet compression, the wrist was exposed through a standard midline dorsal incision. The dorsal wrist capsule was reflected using a ligamentous splitting approach. The lunate was intact within the fossa. There was instability between the lunotriquetral joint with a membranous tear, though the dorsal compartment of the ligament was intact. The scaphoid was successfully reduced into its fossa. The scapholunate (SL) ligament was completely

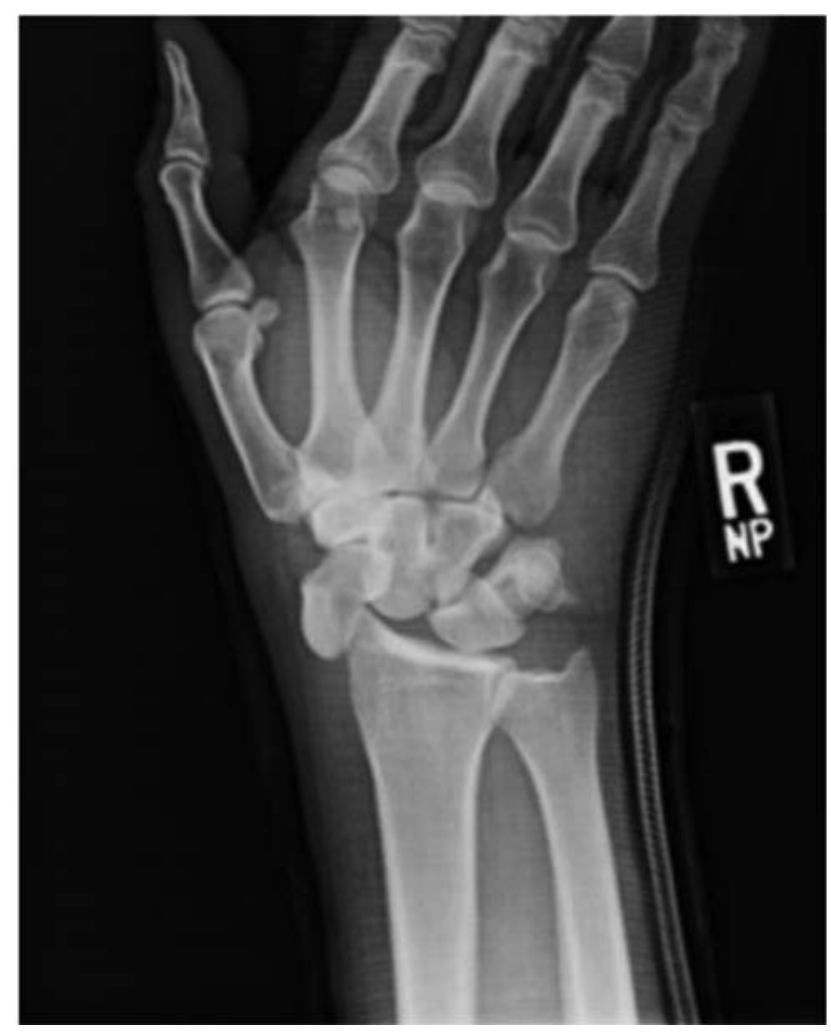

Fig. 1 Anteroposterior radiograph showing acute radial dislocated right scaphoid.

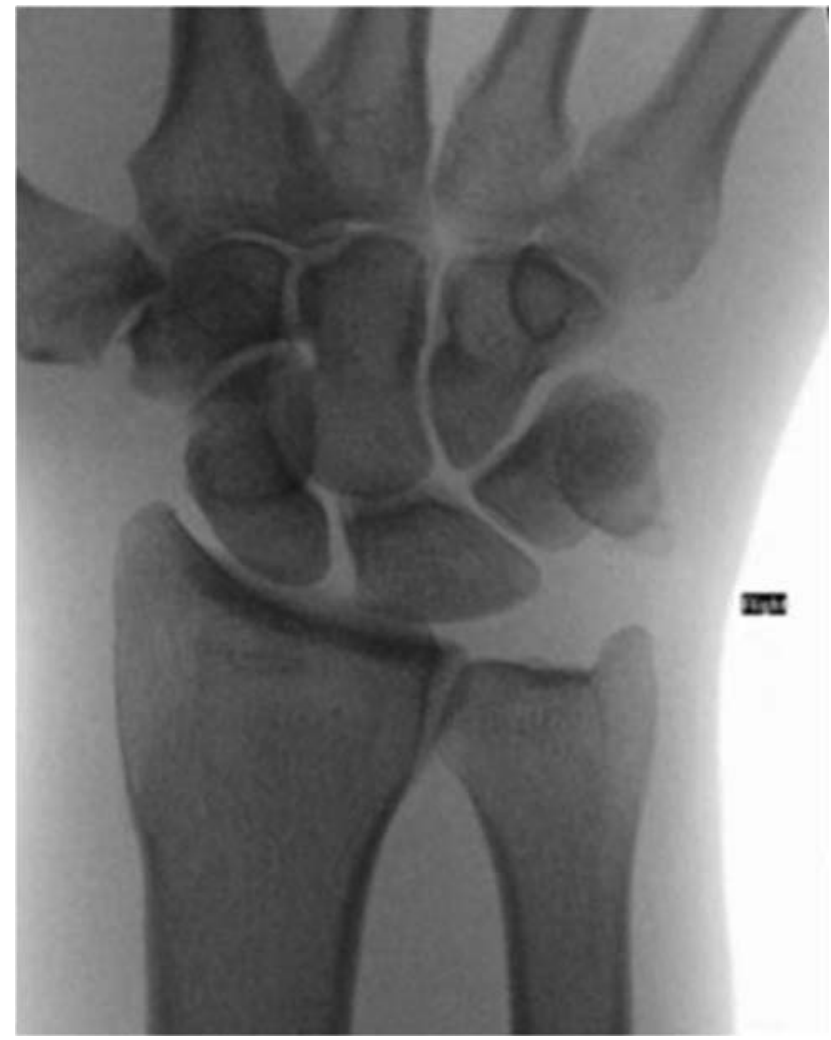

Fig. 2 Fluoroscopic image taken after successful closed reduction.

ruptured. The articular surfaces between the scaphoid and lunate bones were denuded of cartilage down to subchondral bone as one would perform in a RASSEL procedure. Two 0.062 Kirschner's wires (K-wires) were passed transcutaneously through the radial snuff box from the scaphoid into the lunate to hold the scaphoid in a reduced position. An additional wire was placed from the scaphoid into the capitate to stabilize the midcarpal joint. An incision was made over the volar forearm to allow for exploration of the radiocarpal ligaments. The short- and long-radiolunate ligaments were intact, but a tear through the space of Poirier extended from the radioscaphocapitate ligament around the proximal pole of the capitate extending down ulnocapitate ligament. A tear through the radio-SL(the ligament of Testut) was also noted. These volar capsular tears were repaired with sutures (-Fig. 3). Returning to the dorsal incision, suture anchors were placed at the dorsal tubercle of the scaphoid to reconstruct the dorsal capsule and at the tubercle of the triquetrum to allow the reinsertion of the dorsal capsular flap (-Fig. 4). Two $0.062 \mathrm{~K}$-wires were placed between the lunate and triquetrum to stabilize this relationship (-Fig. 5). The dorsal LT-ligament was intact and was therefore not reconstructed; however, an imbrication of the dorsal capsule onto the triquetrum was performed during closure.

\section{Outcome}

After surgery, the patient was maintained in a Münster cast for 6 weeks with K-wire removal at 6 weeks as well. He was provided wrist therapy instruction and completed therapy at 

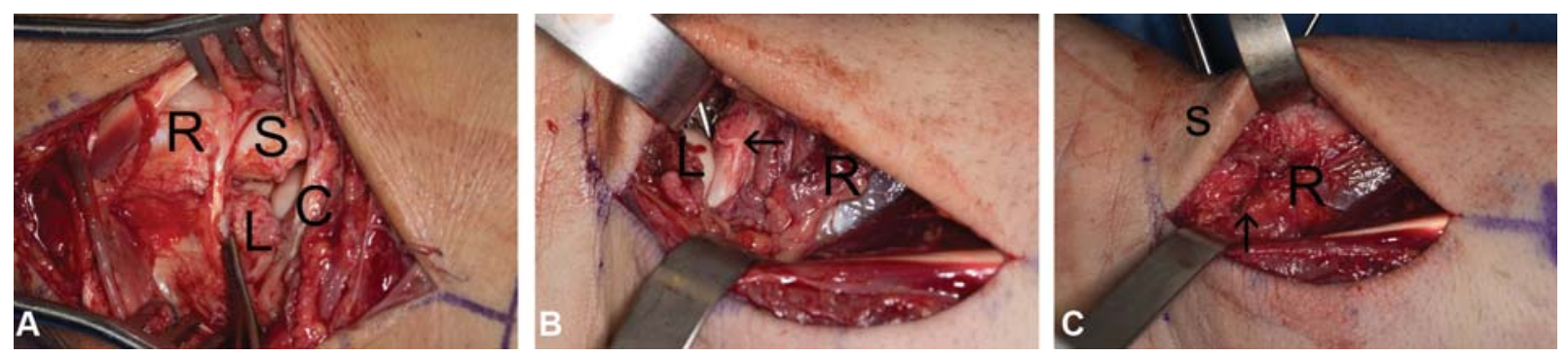

Fig. 3 (A) Operative reduction through dorsal incision. (B) Volar tear through space of Poirier at the radioscaphocapitate ligament. Arrow points to torn radioscaphocapitate ligament (C) Volar tear repaired with sutures. Arrow points to repaired tear through the space of Poirer. R, radius; $S$, scaphoid; L, lunate; C, capitates.

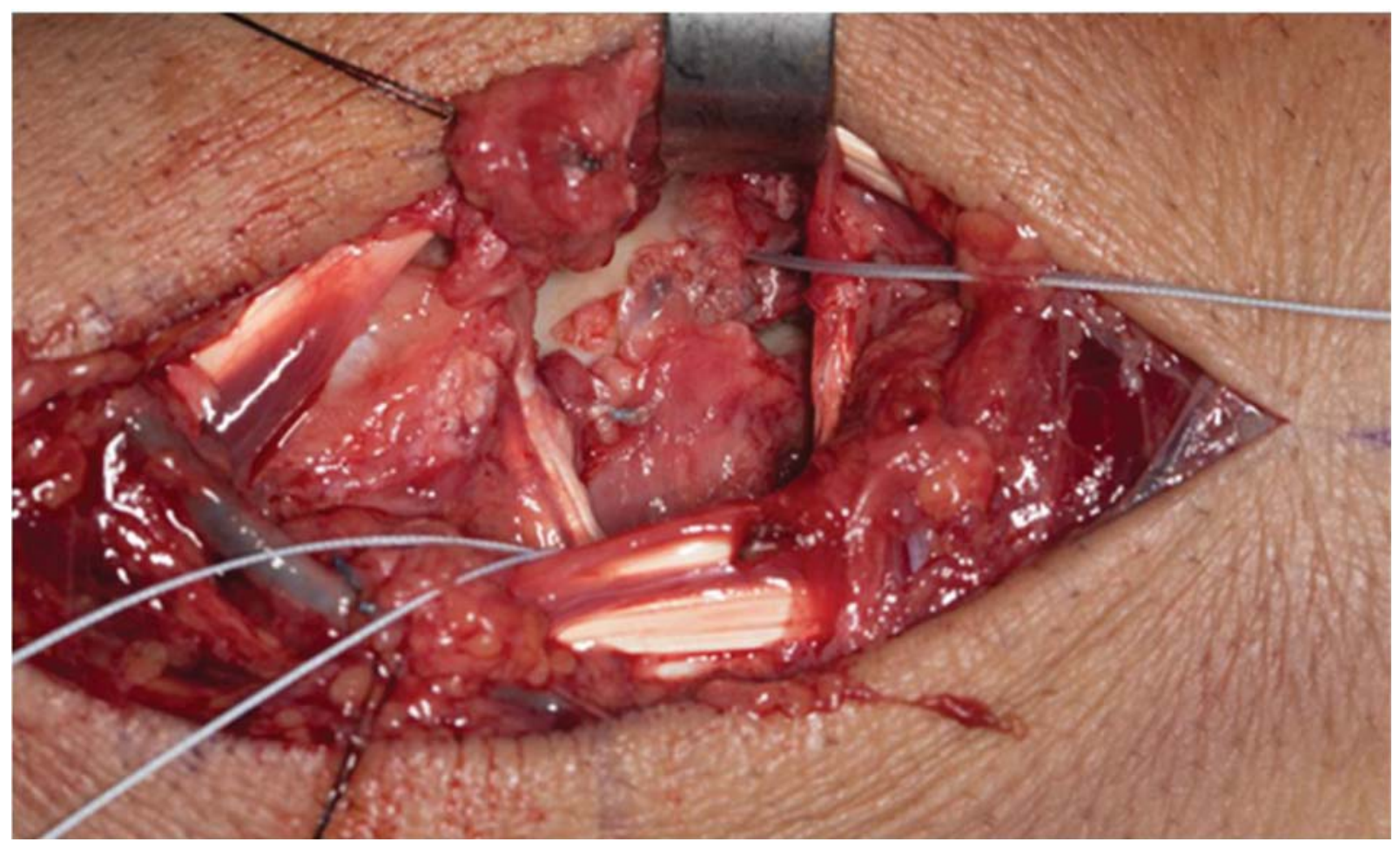

Fig. 4 Suture anchors are placed at dorsal tubercle of the scaphoid to reconstruct the dorsal capsule and the tubercle of the triquetrum.

home. A volar wrist splint was provided for 4 additional weeks for comfort. On 6-month and 24-month follow-up, he was doing well (-Fig. 6). He had no pain and no limitations in his activities of daily living and has returned to farming without restrictions. His exam showed radial deviation 17 degrees (noninjured 20degrees), ulnar deviation 30 degrees (noninjured 40 degrees), flexion 47 degrees (noninjured 70 degrees), extension 30 degrees (noninjured 60 degrees), and grip strength was $40 \mathrm{~kg}$ on the left and $50 \mathrm{~kg}$ on the right.

\section{Discussion}

Solitary scaphoid dislocations are rare, with only 55 total cases reported, yet they have been described since the early 1900 s. The mechanism of injury is commonly hyperextension with axial loading of the wrist. Closed reduction can be difficult and often open reduction is required. To allow the scaphoid bone to fully rotate out of its native position and become dislocated, there must be disruption to the SL interosseous ligament (SLIL), the radioscaphocapitate ligament, the scaphotrapezium ligament, and the dorsal radiocarpal ligament, thus allowing the scaphoid to dissociate from the radius and scaphotrapezial articulations. In partial dislocations, which are more common, the scaphoid remains attached distally to the scaphoid-trapezium-trapizoid (STT) ligaments and the scaphotrapezial articulation. Carpal bone dislocations rarely occur in isolation and are most likely seen as part of a perilunate or axial carpal dissociation pattern. The proximal carpal row is noted to be at a higher risk of dislocations due to its increased mobility compared with the distal row. Horton et al noted that dislocations of the scaphoid can be classified either as (1) isolated to the periscaphoid ligaments or (2) part of a more complex injury, and also the "luxation" can be subdivided into subluxation, proximal dislocation, or total dislocation. ${ }^{4}$

Leung et al described a classification system for the solitary dislocated scaphoid. ${ }^{5}$ The following four different parameters are considered: primary versus secondary, simple versus complex, partial versus total, and direction of dislocation. 

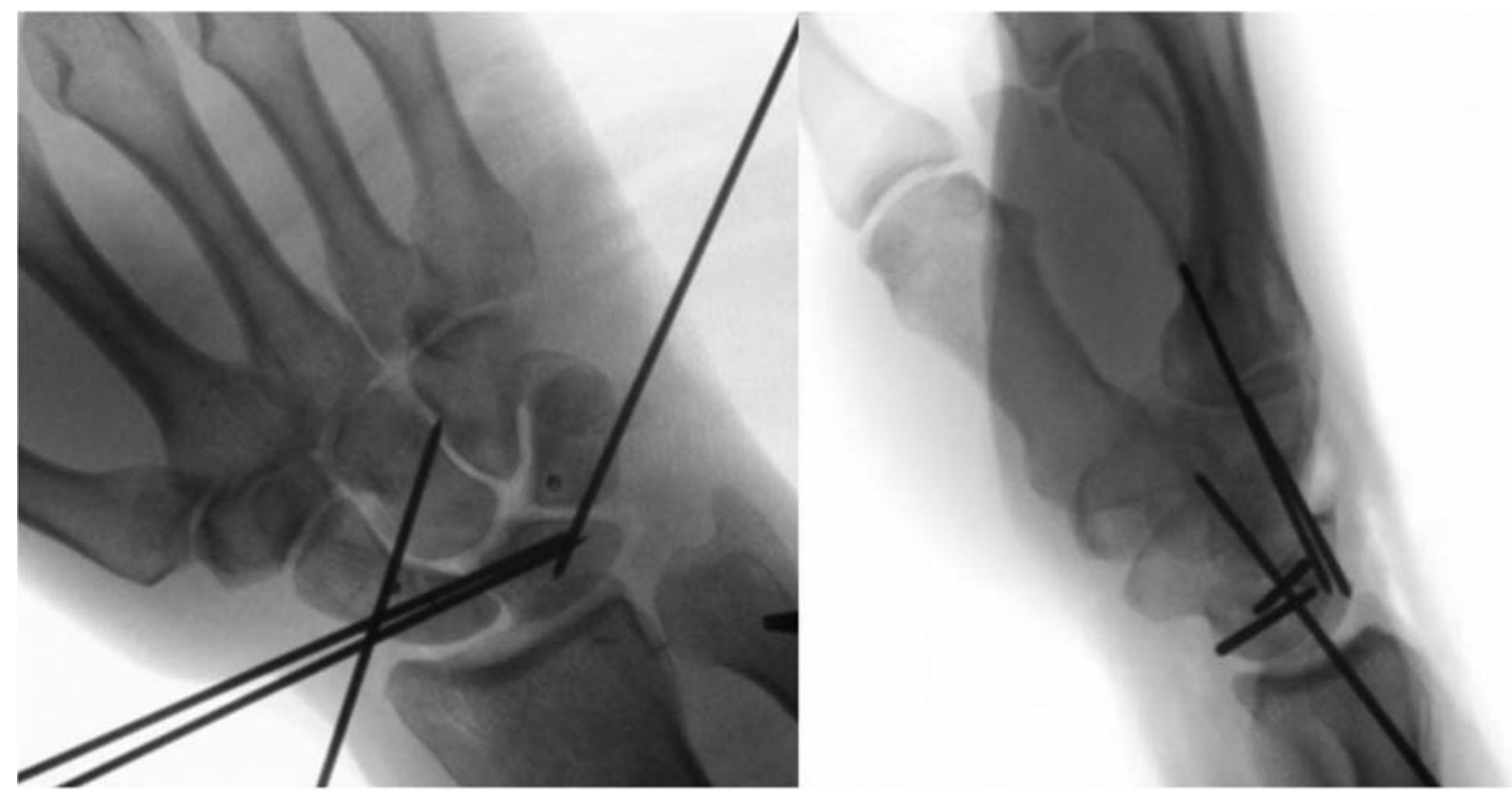

Fig. 5 Intra-operative fluoroscopy showing Kirschner's-wire fixation.

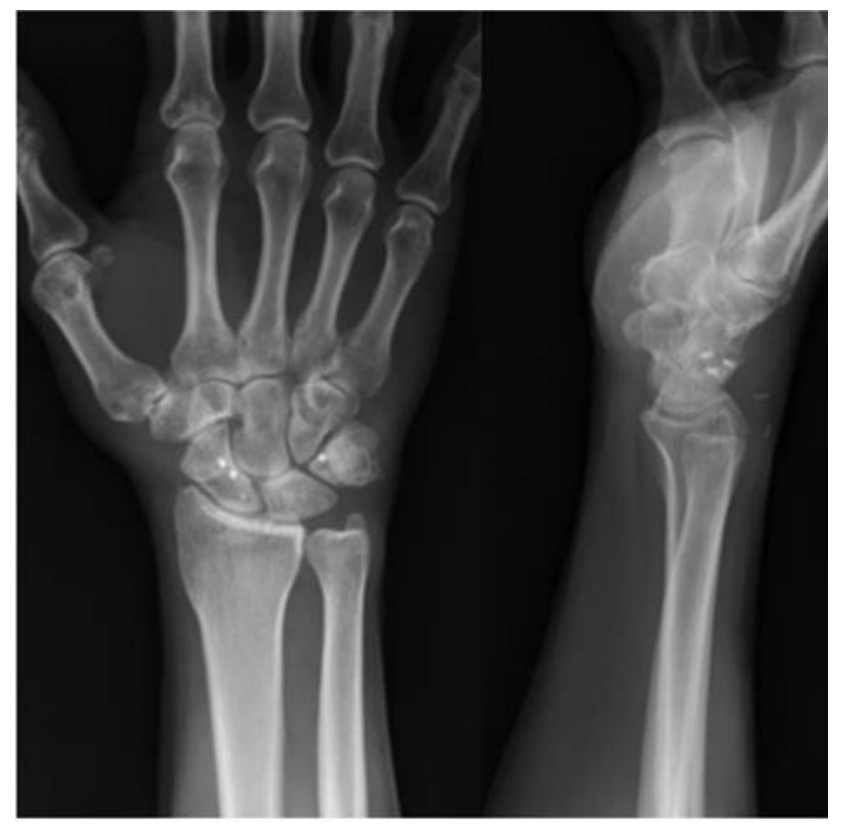

Fig. 6 Final postoperative radiographs showing maintenance of scaphoid reduction and healed pisiform fracture.

Primary dislocations result from injury whereas secondary result from nonanatomic closed reduction of a proximal row carpal bone. Simple dislocations involve only the SL and radioscaphoid articulation. Complex dislocations also disrupt the distal carpal row, most commonly with an axial injury pattern separating the third and fourth MCP joints and the capitohamate articulation. Dislocations can be partial or total with respect to their native soft tissue attachments.

The literature on isolated scaphoid dislocation is limited to single-patient case reports or small case series. - Table 1 provides a comprehensive review of all of the reported cases. $^{1-9}$ The majority of scaphoid dislocations were seen in men (male:female $=46: 3$ ); however, the age range was noted to be between 18 to 79 years. The main mechanism was a motor vehicle accident with a forced dorsiflexion and twisting motion of the wrist. Nearly half of the cited cases had delayed diagnosis with the longest interval being 6 years. ${ }^{2,3,5,6}$ Approximately, half of the cases were treated with operative fixation with only one case with a total dislocation noted to have avascular necrosis. ${ }^{8}$ Even then the necrosis was relatively asymptomatic and limited to the proximal pole. This paucity of necrosis is surprising, especially in cases where the dislocation is total. There were even cases where the scaphoid was completely removed from the patient and replaced and none of these cases reported avascular necrosis. ${ }^{9}$ This lack of avascular necrosis is postulated to result from the intact intraosseous vascular channels within the scaphoid bone. ${ }^{5}$ All attempts should be made to preserve the radial soft tissue attachments to the distal pole and dorsal ridge to maximize blood supply if surgery is to be performed. ${ }^{10}$

If there is a partial dislocation then closed reduction with 4 to 6 weeks of immobilization has been performed. Cases of delayed diagnosis typically require operative treatment for reduction because of changes to the soft tissues. If the delay is more than a several months then secondary finger and wrist stiffness, as well as arthritic changes, within the intercarpal and radiocarpal joint can arise. Ultimately, arthrodesis or even proximal row carpectomy in these instances may be needed for pain control. ${ }^{5}$

Type-II lunates appear to confer some protection against carpal injury. Viegas et al has described the lunate into two types. ${ }^{11}$ Type-II lunates have medial facet that articulates with the hamate while type-I lunates do not have this facet. Only eight cases were associated with a type-II lunate (-Table 2). This medial facet of the lunate may confer more load to the wrist's central column making the scaphoid 
Table 1 A comprehensive review of all of the reported cases

\begin{tabular}{|c|c|c|c|c|c|}
\hline Study (year) & $\begin{array}{l}\text { Age } \\
\text { Sex } \\
\text { Side }\end{array}$ & Dx & Dislocation & $\begin{array}{l}\text { Surgical } \\
\text { approach }\end{array}$ & Outcome \\
\hline Akinci $(1)^{11}(2012)$ & $\begin{array}{l}32 \\
M \\
L\end{array}$ & $5 \mathrm{mo}$ & Palmar & - & $\begin{array}{l}\text { Injured wrist flexion/extension: 55/55 degrees, grip } \\
\text { strength: injured } 38 \mathrm{~kg}\end{array}$ \\
\hline Akinci $(2)^{11}(2012)$ & $\begin{array}{l}46 \\
M \\
R\end{array}$ & $7 \mathrm{mo}$ & Radial-palmar & - & $\begin{array}{l}\text { Injured wrist flexion/extension: 65/55 degrees, grip } \\
\text { strength: injured } 34 \mathrm{~kg}\end{array}$ \\
\hline Akinci $(3)^{11}(2012)$ & $\begin{array}{l}71 \\
M \\
R\end{array}$ & $4 \mathrm{mo}$ & Radial-palmar & - & $\begin{array}{l}\text { Injured wrist flexion/extension: 40/60 degrees, grip } \\
\text { strength: injured } 25 \mathrm{~kg}\end{array}$ \\
\hline Amamilo et al $\left.\right|^{3}$ (1985) & $\begin{array}{l}63 \\
M \\
L\end{array}$ & $5 \mathrm{~d}$ & Radial & Palmar & Almost full ROM, no residual pain \\
\hline Amaravati $^{12}$ (2009) & $\begin{array}{l}45 \\
M \\
L\end{array}$ & $2.5 \mathrm{mo}$ & Dorsal & Dorsal & Cooney wrist score 85 points \\
\hline Antuna $^{13}$ (1997) & $\begin{array}{l}32 \\
M \\
L\end{array}$ & $0 \mathrm{~d}$ & Open palmar & $\begin{array}{l}\text { Dorsal } \\
\text { and palmar }\end{array}$ & $\begin{array}{l}\text { Wrist flexion/extension: 60/30 degrees, ulnar/radial } \\
\text { deviation: } 30 / 10 \text { degrees }\end{array}$ \\
\hline Baek et $\mathrm{al}^{6}(2016)$ & $\begin{array}{l}40 \\
M \\
R\end{array}$ & $2 \mathrm{mo}$ & Palmar & Dorsal & $\begin{array}{l}\text { Flexion/extension: 60/55 degrees, ulnar/radial devi- } \\
\text { ation } 25 / 15 \text { degrees, grip strength } 21 \mathrm{~kg}\end{array}$ \\
\hline Buzby $^{14}(1934)$ & $\begin{array}{l}47 \\
M \\
L\end{array}$ & $3 d$ & Radial & Radial & 10-degree loss of wrist flexion and extension \\
\hline Chloros $^{15}(2006)$ & $\begin{array}{l}28 \\
M \\
R\end{array}$ & $0 \mathrm{~d}$ & Radial-palmar & Palmar & $\begin{array}{l}\text { Flexion/extension: } 75 / 70 \text { degrees, ulnar/radial devia- } \\
\text { tion: } 25 / 20 \text { degrees }\end{array}$ \\
\hline Connell $^{16}(1955)$ & $\begin{array}{l}36 \\
M \\
R \\
\end{array}$ & $0 \mathrm{~d}$ & Radial & - & Full ROM, returned to heavy manual work \\
\hline Ely $^{1}(1903)$ & $\begin{array}{l}25 \\
M \\
R\end{array}$ & $1 \mathrm{~d}$ & Dorsal & - & Good ROM \\
\hline Engkvist $^{17}$ (1986) & $\begin{array}{l}71 \\
M \\
R\end{array}$ & $0 \mathrm{~d}$ & Radial-palmar & Palmar & $\begin{array}{l}50 \% \text { grip strength compared with non-injured hand, } \\
\text { dorsovolar ROM } 50 \text { degrees injured wrist }\end{array}$ \\
\hline Fishman $^{18}$ (1985) & $\begin{array}{l}26 \\
M \\
R \\
\end{array}$ & $4 \mathrm{w}$ & Palmar & - & - \\
\hline Higgs $^{19}$ (1929) & $\begin{array}{l}41 \\
M \\
R\end{array}$ & $8 w k$ & Radial-palmar & Radial & Good ROM, \\
\hline Higgs $(2)^{19}(1929)$ & $\begin{array}{l}48 \\
M \\
R\end{array}$ & $3.5 \mathrm{wk}$ & Radial & - & Good grip and good \\
\hline Horton et al ${ }^{4}(2004)$ & $\begin{array}{l}33 \\
M \\
R\end{array}$ & $0 \mathrm{~d}$ & Radial & - & Wrist flexion/extension: 55/65 degrees \\
\hline Inoue $^{20}(1990)$ & $\begin{array}{l}18 \\
M \\
L\end{array}$ & $14 \mathrm{~d}$ & Dorsal & Dorsal & $\begin{array}{l}\text { Flexion/extension: 50/60 degrees, ulnar/radial devi- } \\
\text { ation: 30/15 degrees }\end{array}$ \\
\hline Kennedy $^{21}(2006)$ & $\begin{array}{l}36 \\
M \\
L\end{array}$ & $0 \mathrm{~d}$ & Palmar & Radio-dorsal & $\begin{array}{l}\text { 20-degree loss of wrist extension, 10-degree loss of } \\
\text { flexion }\end{array}$ \\
\hline Kiliç $^{22}(2012)$ & $\begin{array}{l}25 \\
M \\
R\end{array}$ & $0 \mathrm{~d}$ & Palmar & Palmar & $\begin{array}{l}\text { Wrist flexion: } 50 \text { degrees compared with 65-degree } \\
\text { noninjured side, all other ROM equal to noninjured } \\
\text { side }\end{array}$ \\
\hline
\end{tabular}


Isolated Scaphoid Dislocation Amundsen et al.

Table 1 (Continued)

\begin{tabular}{|c|c|c|c|c|c|}
\hline Study (year) & $\begin{array}{l}\text { Age } \\
\text { Sex } \\
\text { Side }\end{array}$ & Dx & Dislocation & $\begin{array}{l}\text { Surgical } \\
\text { approach }\end{array}$ & Outcome \\
\hline Kolby $^{23}(2007)$ & $\begin{array}{l}18 \\
M \\
L\end{array}$ & $14 \mathrm{~d}$ & Palmar & Palmar & $\begin{array}{l}\text { Flexion/extension: } 45 / 35 \text { degrees, ulnar/radial devia- } \\
\text { tion: } 30 / 20 \text { degrees, grip strength: } 35 \mathrm{~kg}\end{array}$ \\
\hline Kuth $^{24}$ (1939) & $\begin{array}{l}52 \\
M \\
L\end{array}$ & $0 \mathrm{~d}$ & Radial & - & $20^{\circ}$ loss of extension, 15 -degree loss of flexion \\
\hline Leung et $\mathrm{al}^{5}$ (1998) & $\begin{array}{l}26 \\
M \\
R\end{array}$ & $21 \mathrm{~d}$ & Palmar-ulnar & Palmar & $\begin{array}{l}\text { Wrist flexion/extension: } 45 / 60 \text { degrees, ulnar/radial } \\
\text { deviation: } 25 / 15 \text { degrees, grip strength } 35 \mathrm{~kg}\end{array}$ \\
\hline Maki $^{25}(1982)$ & $\begin{array}{l}40 \\
M \\
L\end{array}$ & $0 \mathrm{~d}$ & Radial & - & Full ROM, \\
\hline McNamara $^{9}$ (1992) & $\begin{array}{l}23 \\
M \\
L\end{array}$ & $0 \mathrm{~d}$ & Palmar & Palmar & Extension/flexion 40/65 degrees \\
\hline Milankov $(1)^{26}(1994)$ & $\begin{array}{l}43 \\
F \\
R\end{array}$ & $0 \mathrm{~d}$ & Palmar-radial & - & Full ROM, no pain \\
\hline Milankov $(2)^{26}(1994)$ & $\begin{array}{l}35 \\
M \\
R\end{array}$ & $0 \mathrm{~d}$ & Palmar & - & Full ROM, no pain \\
\hline Parkes $(1)^{27}(1973)$ & $\begin{array}{l}48 \\
M \\
L\end{array}$ & $1 \mathrm{mo}$ & Dorsal & Dorsal & - \\
\hline Parkes $(2)^{27}(1973)$ & $\begin{array}{l}50 \\
M \\
R\end{array}$ & $23 d$ & Dorsal & Dorsal & - \\
\hline Reid $^{7}$ (1969) & $\bar{R}$ & - & Palmar & - & - \\
\hline Ritchie $^{28}(1988)$ & $\begin{array}{l}39 \\
M \\
L\end{array}$ & $0 \mathrm{~d}$ & Palmar-radial & Radial & Full ROM, no pain \\
\hline Richards $^{29}(1993)$ & $\begin{array}{l}49 \\
F \\
R\end{array}$ & $7 \mathrm{~d}$ & Dorsal & Dorsal & - \\
\hline Russell $^{30}$ (1949) & $\begin{array}{l}? \\
M \\
R\end{array}$ & $0 \mathrm{~d}$ & Dorsal & - & Retained 75-degree ROM \\
\hline Schlossbach $^{31}$ (1954) & $\begin{array}{l}26 \\
M \\
R\end{array}$ & $4 \mathrm{~d}$ & - & - & Regained full use of wrist without pain \\
\hline Szabo $^{8}(1)(1995)$ & $\begin{array}{l}38 \\
M \\
R\end{array}$ & $0 \mathrm{~d}$ & Radiopalmar & Dorsal ports & Full ROM, grip strength: $50 \mathrm{~kg}$ \\
\hline Szabo $^{8}(2)(1995)$ & $\begin{array}{l}67 \\
F \\
L\end{array}$ & $0 \mathrm{~d}$ & Radiopalmar & Dorsal & $\begin{array}{l}\text { Flexion/extension } 53 \text { / } 45 \text { degrees, ulnar/radial devia- } \\
\text { tion } 25 / 35 \text { degrees, grip strength: } 21 \mathrm{~kg}\end{array}$ \\
\hline Szabo $^{8}$ (3) (1995) & $\begin{array}{l}34 \\
M \\
L\end{array}$ & $0 \mathrm{~d}$ & Radiopalmar & Dorsal & $\begin{array}{l}\text { AVN proximal pole scaphoid, flexion/extension: } 30 / \\
25 \text { degrees, ulnar/radial deviation: } 15 / 5 \text { degrees, grip } \\
\text { strength: } 41 \mathrm{~kg}\end{array}$ \\
\hline Sides $^{32}(1995)$ & $\begin{array}{l}38 \\
M \\
R\end{array}$ & $1 \mathrm{~d}$ & Radiopalmar & - & Equal strength bilaterally \\
\hline Sides $(2)^{32}(1995)$ & $\begin{array}{l}67 \\
W \\
L\end{array}$ & $0 \mathrm{~d}$ & Radial & - & - \\
\hline
\end{tabular}


Table 1 (Continued)

\begin{tabular}{|c|c|c|c|c|c|}
\hline Study (year) & $\begin{array}{l}\text { Age } \\
\text { Sex } \\
\text { Side }\end{array}$ & Dx & Dislocation & $\begin{array}{l}\text { Surgical } \\
\text { approach }\end{array}$ & Outcome \\
\hline Somford $^{33}(2010)$ & $\begin{array}{l}47 \\
M \\
L\end{array}$ & $0 \mathrm{~d}$ & Radio-palmar & Palmar & $\begin{array}{l}\text { Flexion/extension: 50/50 degrees, radial/ulnar devia- } \\
\text { tion: } 20 / 40 \text { degrees, grip strength: } 25 \mathrm{~kg}\end{array}$ \\
\hline Stambough $^{34}(1986)$ & $\begin{array}{l}21 \\
M \\
R\end{array}$ & $3 \mathrm{mo}$ & Palmar & Palmar & $\begin{array}{l}\text { Flexion/extension: } 70 / 35 \text { degrees, ulnar/radial devia- } \\
\text { tion: } 30 / 10 \text { degrees, } 85 \% \text { grip strength compared with } \\
\text { noninjured side }\end{array}$ \\
\hline Takami $^{2}(1992)$ & $\begin{array}{l}45 \\
M \\
R\end{array}$ & $8 \mathrm{mo}$ & Palmar-ulnar & $\begin{array}{l}\text { Dorsal-radial } \\
\text { and palmar }\end{array}$ & $\begin{array}{l}\text { 75\% normal extension, } 65 \% \text { normal flexion, grip } \\
\text { strength: } 30 \mathrm{~kg}\end{array}$ \\
\hline Taylor (1) (1969) & $\begin{array}{l}20 \\
M \\
L\end{array}$ & $0 \mathrm{~d}$ & Palmar & - & Full wrist ROM, normal strength, \\
\hline Taylor (2) (1969) & $\begin{array}{l}48 \\
M \\
L\end{array}$ & $0 \mathrm{~d}$ & Radial & - & Full function, returned to work \\
\hline Thomas $^{35}$ (1977) & $\begin{array}{l}23 \\
M \\
R\end{array}$ & $0 \mathrm{~d}$ & Radial & - & - \\
\hline Thompson $(1)^{36}(1964)$ & $\begin{array}{l}37 \\
M \\
L\end{array}$ & $0 \mathrm{~d}$ & Dorsal & Palmar & $\begin{array}{l}50 \% \text { loss of wrist extension, } 33 \% \text { loss of wrist flexion, } \\
\text { no pain, }\end{array}$ \\
\hline Thompson $(2)^{36}(1964)$ & $\begin{array}{l}39 \\
M \\
R\end{array}$ & $9 \mathrm{mo}$ & Dorsal & - & Persistent pain with radiocapitate arthrodesis \\
\hline Thompson $(3)^{36}(1964)$ & $\begin{array}{l}30 \\
M \\
L\end{array}$ & $1 \mathrm{mo}$ & Dorsal & Dorsal & Good ROM \\
\hline Thompson $(4)^{36}(1964)$ & $\begin{array}{l}30 \\
\mathrm{M} \\
\mathrm{L}\end{array}$ & $1.5 \mathrm{mo}$ & Dorsal & - & Returned to work \\
\hline Thompson $(5)^{36}(1964)$ & $\begin{array}{l}56 \\
M \\
L\end{array}$ & $9 \mathrm{mo}$ & Dorsal & - & Persistent pain but refused treatment \\
\hline Thompson $(6)^{36}(1964)$ & $\begin{array}{l}79 \\
M \\
L\end{array}$ & od & Dorsal & - & - \\
\hline Thompson $(7)^{36}(1964)$ & $\begin{array}{l}60 \\
M \\
L\end{array}$ & $0 \mathrm{~d}$ & Dorsal & - & Persistent pain, taken for radiocapitate arthrodesis \\
\hline Thompson $(8)^{36}(1964)$ & $\begin{array}{l}45 \\
M \\
R\end{array}$ & $6 y$ & Dorsal & - & - \\
\hline Walker $^{37}(1943)$ & $\begin{array}{l}44 \\
M \\
R\end{array}$ & $9 \mathrm{~d}$ & Radial & Radial & 5-degree loss of wrist extension, no pain \\
\hline Wong $^{38}(2015)$ & $\begin{array}{l}68 \\
M \\
L\end{array}$ & $0 \mathrm{~d}$ & Palmar & Palmar & Pain free and full function \\
\hline Yasuda ${ }^{39}$ & $\begin{array}{l}57 \\
M \\
L\end{array}$ & $0 \mathrm{~d}$ & Palmar-radial & Palmar & Full ROM and no pain \\
\hline
\end{tabular}

Abbreviations: AVN, avascular necrosis; F, female; K-wires, Kirschner’s wires; L, left; M, male; R, right; ROM, range of motion.

less susceptible to dislocation during ulnar deviation and wrist extension.

The direction of dislocation can also provide insight into possible neurovascular injury. Median nerve compression can result from dislocations oriented palmar and ulnarly. ${ }^{2}$ Open reduction is also warranted for palmar and ulnar dislocations due to the concern for median nerve compression and thus simultaneous release of the carpal tunnel can 
Table 2 Descriptions of type-I and type-II lunates

\begin{tabular}{|c|c|}
\hline Study & Lunate type \\
\hline Akinci (1) & I \\
\hline Akinci (2) & 1 \\
\hline Akinci (3) & 1 \\
\hline Amamilo et $\mathrm{al}^{3}$ & 1 \\
\hline Amaravati & Unable to determine \\
\hline Antuna & 1 \\
\hline${\text { Baek et } \mathrm{al}^{6}}^{6}$ & 1 \\
\hline Buzby & 1 \\
\hline Chloros & I \\
\hline Connell & 1 \\
\hline Ely $^{1}$ & Unable to determine \\
\hline Engkvist & I \\
\hline Fishman & 1 \\
\hline Higgs (1) & II \\
\hline Higgs (2) & II \\
\hline Horton et $\mathrm{al}^{4}$ & II \\
\hline Inoue & I \\
\hline Kennedy & I \\
\hline Kiliç & 1 \\
\hline Kolby & 1 \\
\hline Kuth & 1 \\
\hline Leung et $\mathrm{al}^{5}$ & 1 \\
\hline Maki & 1 \\
\hline McNamara $^{9}$ & 1 \\
\hline Milankov (1) & Unable to determine \\
\hline Milankov (2) & Unable to determine \\
\hline Moran & 1 \\
\hline Parkes (1) & Unable to determine \\
\hline Parkes (2) & Unable to determine \\
\hline Reid $^{7}$ & Unable to determine \\
\hline Ritchie & 1 \\
\hline Richards & 1 \\
\hline Russell & Unable to determine \\
\hline Schlossbach & I \\
\hline Szabo $^{8}(1)$ & I \\
\hline Szabo $^{8}(2)$ & 1 \\
\hline Szabo $^{8}(3)$ & 1 \\
\hline Sides & Unable to determine \\
\hline Sides & Unable to determine \\
\hline Somford & Unable to determine \\
\hline Stambough & I \\
\hline Takami $^{2}$ & Unable to determine \\
\hline Taylor (1) & II \\
\hline Taylor (2) & I \\
\hline
\end{tabular}

be performed. Surgical approaches via palmar or dorsal incisions are typically based on the direction of dislocation.

Throughout the early-to-mid 1900s, all scaphoid dislocations that were able to be reduced treated with closed reduction and splinting definitively, though few studies note longterm follow-up. ${ }^{1}$ In 1969, Reid et al used K-wires to assure fixation of the scaphoid. ${ }^{7}$ Ligamentous repair was not performed until 1985 by Amamilo et al and did not become preferred until after 2000., 3,6,8 Current literature favors ligament repair with open reduction to restore normal anatomy and preserve function. Despite the method of treatment and the totality of dislocation or ligamentous injuries, most patients preserve wrist motion but suffer from mild pain and decreased wrist range of motion. It appears that primary repair with open reduction and ligament repair yields better results as almost all patients reported the ability to return to prior work ( - Video 1; available online only). ${ }^{4}$ Delay to presentation and diagnosis represents the greatest risk factor for poor outcome. ${ }^{3}$ Notwithstanding, Baek et al assert that accurate anatomic reduction, ligament repair, and secure fixation have the most impact on prognosis. ${ }^{6}$ This case report would also support early operative intervention.

\section{Video 1 \\ The range of motion. Online content including video sequences viewable at: https://www.thieme-connect. com/products/ejournals/html/10.1055/s-0040- 1710395.}

\section{Conclusion}

Isolated scaphoid dislocations are rare. Open reduction and ligament fixation are the current treatments of choice, with 
surgical approach dictated by the location of the dislocation. Despite the damage to the soft tissue attachments, the incidence of avascular necrosis with this injury pattern is low. ${ }^{5}$ Type-II lunates appear to be protective for this form of carpal dislocation. When identified early, isolated scaphoid dislocations has good prognosis with operative treatment.

Note

The Work was performed at the Mayo Clinic, Rochester, MN.

\section{Conflict of Interest}

None declared.

\section{References}

1 Ely LW. VI. Dislocation of the carpal scaphoid. Ann Surg 1903;38 (01):97-98.1

2 Takami H, Takahashi S, Ando M. Dislocation of the carpal scaphoid associated with median nerve compression: case report. J Trauma 1992;33(06):921-923

3 Amamilo SC, Uppal R, Samuel AW. Isolated dislocation of carpal scaphoid. J Hand Surg [Br] 1985;10(03):385-388

4 Horton T, Shin AY, Cooney WP III. Isolated scaphoid dislocation associated with axial carpal dissociation: an unusual injury report. J Hand Surg Am 2004;29(06):1102-1108

5 Leung YF, Wai YL, Kam WL, Ip PS. Solitary dislocation of the scaphoid. From case report to literature review. J Hand Surg [Br] 1998;23(01):88-92

6 Baek JR, Cho SH, Lee YS, Roh YH. Neglected isolated scaphoid dislocation. Indian J Orthop 2016;50(06):693-696

7 Reid JM. Isolated dislocation of the carpal scaphoid. Australas Radiol 1969;13(04):376-379

8 Szabo RM, Newland CC, Johnson PG, Steinberg DR, Tortosa R. Spectrum of injury and treatment options for isolated dislocation of the scaphoid. A report of three cases. J Bone Joint Surg Am 1995; 77(04):608-615

9 McNamara MG, Corley FG. Dislocation of the carpal scaphoid: an 8-year follow-up. J Hand Surg Am 1992;17(03):496-498

10 Morsy M, Sabbagh MD, van Alphen NA, Laungani AT, Kadar A, Moran SL. The Vascular anatomy of the scaphoid: new discoveries using micro-computed tomography imaging. J Hand Surg Am 2019;44(11):928-938

11 Akinci M, Yildirim AO, Kati YA. Late-presenting, isolated, complete radial dislocations of the scaphoid treated with the Szabo technique. J Hand Surg Eur Vol. 2012;37(09):901-903

12 Amaravati RS, Saji M, Rajagopal H, Gururaj. Neglected dorsal dislocation of the scaphoid. Indian J Orthop. 2009;43(02):213215

13 Antuna SA, Antuna-Zapico JM. Open dislocation of the carpal scaphoid: a case report. J Hand Surg Am. 1997;22(01):86-88

14 Buzby B. Isolated radial dislocation of carpal scaphoid. Ann Surg. 1934(100):553-555

15 Chloros GD, Themistocleous GS, Zagoreos NP, Korres DS, Efstathopoulos DG, Soucacos PN. Isolated dislocation of the scaphoid. Arch Orthop Trauma Surg. 2006;126(03):197-203
16 Connell MC, Dyson RP. Dislocation of the carpal scaphoid; report of a case. J Bone Joint Surg Br. 1955;37-B(02):252-253

17 Engkvist O, Ekenstam F. Closed dislocation of the scaphoid. A case report and review of the literature. Scand J Plast Reconstr Surg. 1986;20(02):239-242

18 Fishman MC, Dalinka MK, Osterman L. Case report 309. Diagnosis: complete volar subluxation of the right scaphoid bone and fracture of the right capitate bone. Skeletal Radiol. 1985;13(03):245-7

19 Higgs SL. Two Cases of Dislocation of Carpal Scaphoid. Proc R Soc Med. 1930 Jul;23(09):1337-1339

20 Inoue G, Maeda N. Isolated dorsal dislocation of the scaphoid. J Hand Surg Br. 1990;15(03):368-369

21 Kennedy JG, O'Connor P, Brunner J, Hodgkins C, Curtin J. Isolated carpal scaphoid dislocation. Acta Orthop Belg. 2006;72(04):478-483

22 Kilic M, Kalali F, Unlu M, Yildirim OS. Isolated carpal scaphoid dislocation. Acta Orthop Traumatol Turc. 2012;46(01):68-71

23 Kolby L, Larsen S, Jorring S, Sorensen AI, Leicht P. Missed isolated volar dislocation of the scaphoid. Scand J Plast Reconstr Surg Hand Surg. 2007;41(05):264-266

24 Kuth J. Isolated dislocation of the carpal navicular: a case report. J Bone and Joint Surg. 1939;21(02):479-483

25 Maki NJ, Chuinard RG, D'Ambrosia R. Isolated, complete radial dislocation of the scaphoid. A case report and review of the literature. J Bone Joint Surg Am. 1982;64(04):615-616

26 Milankov M, Somer T, Jovanovic A, Brankov M. Isolated dislocation of the carpal scaphoid: two case reports. J Trauma. 1994;36 (05):752-754

27 Parkes JC, Stovell PB. Dislocation of the carpal scaphoid: a report of two cases. J Trauma. 1973;13(04):384-388

28 Ritchie DA, Gibson PH. Isolated dislocation of the scaphoid. Injury. 1988;19(06):405-406

29 Richards RS, Bennett JD, Roth JH. Scaphoid dislocation with radialaxial carpal disruption. AJR Am J Roentgenol. 1993;160(05):10751076

30 Russell TB. Inter-carpal dislocations and fracture-dislocations; a review of 59 cases. J Bone Joint Surg Br. 1949;31B(04):524-531, illust

31 Schlossbach T. Dislocation of the carpal navicular bone not associated with fracture. J Med Soc N J. 1954;51(12):533-534

32 Sides D, Laorr A, Greenspan A. Carpal scaphoid: radiographic pattern of dislocation. Radiology. 1995;195(01):215-216

33 Somford MP, Sturm MF, Vroemen JP. Reconstruction of isolated scaphoid dislocation with carpal dissociation, associated with a carpal anomaly. Strategies Trauma Limb Reconstr. 2010;5 (02):105-110

34 Stambough JL, Mandel RJ, Duda JR. Volar dislocation of the carpal scaphoid. Case report and review of the literature. Orthopedics. 1986;9(04):565-570

35 Thomas HO. Isolated dislocation of the carpal scaphoid. Acta Orthop Scand. 1977;48(04):369-372

36 Thompson TC, Campbell RD, Jr., Arnold WD. Primary and Secondary Dislocation of the Scaphoid Bone. J Bone Joint Surg Br. 1964;46:73-82

37 Walker G. Dislocation of the carpal scaphoid reduced by open operation. Br J Surg. 1943(30):380-381

38 Wong KY, Johnston P. Isolated scaphoid fracture with palmar dislocation of the proximal fragment. BMJ Case Rep. 2015;2015

39 Yasuda T. Isolated dislocation of the carpal scaphoid: a case report. Nihon Geka Hokan. 1997;66(02):59-65 